\title{
PEDAGOGICAL ASSISTANCE TO "LINGVA" PROGRAM PARTICIPANTS PROFESSIONAL WRITING SKILLS FORMATION AT THE ELEMENTARY STAGE OF LANGUAGE TRAINING
}

\author{
M.V. Tsytovich, tcytovichmv@susu.ru \\ South Ural State University, Chelyabinsk, Russian Federation
}

\begin{abstract}
This article explains the importance of the formation of academic staff competence in foreign language writing caused by the need of publishing articles in peer-reviewed journals included in Scopus and Web of Science databases. When analyzing the literature we revealed some specific features of pedagogical assistance, which make it the most appropriate form of educational and pedagogical interaction with the adult audience. The concept "assistance" was defined with regard to the formation of academic writing skills for a university. The sociological survey and professional activity analysis have shown that a professional lecturer writing skills include two components: writing for teaching purposes and academic writing. The study resulted in the list of competences each university lecturer should perform using professional writing skills in a foreign language. The results can be used for the development of the retraining programs and for the advanced training of academic staff.

Keywords: pedagogical assistance, educational and pedagogical interaction, academic writing, academic staff.
\end{abstract}

Problem statement. Nowadays one of the major tasks for Russian universities, going global, is integration into the world educational space. In the federal law "On Education in the Russian Federation" the need for our educational institutions joining in the rankings of the best universities in the world is clearly defined [3]. One of the requirements is the active participation of the faculty members in international scientific conferences and publication of articles in peerreviewed journals included in Scopus and Web of Science database. High level language proficiency is necessary to achieve these professional goals.

The study on the linguistic competence using in research activities has shown that $76.8 \%$ of researchers and lecturers of non-linguistic areas use a foreign language to read literature in the original, $73.0 \%$ - to take part in scientific conferences, $88.3 \%$ - to write research papers and abstracts for Russian and foreign journals [14]. These activities involve mainly lecturers with a high level of language proficiency - Advanced, Intermediate, Upper-Intermediate, which is from $5 \%$ to $15 \%$ of the University teaching staff [8].

To resolve the contradiction between the need to participate in international conferences and publish articles in English and the lack of the teaching staff linguistic training linguistic retraining programs and teaching staff advanced training are implemented in the South Ural State University (SUSU), the "Lingva" program, started in 2006 year, is among them [7]. There are more than 10 multi-level groups in this program each year; half of them are the groups of Elementary and Pre-Intermediate levels. These level students are considered not to be ready to take part in international professional activities, so the analysis of the linguistic competence usage for professional tasks solving was carried out only in Advanced, Intermediate, Upper-Intermediate level groups.

Similar analysis of professional tasks was carried out in lower level groups, taking into account the fact that it is prospective by nature. It was revealed that students of these groups use English to write abstracts for papers (100\%). The major aims and objectives of language training for them are the following: scientific literature reading in the original $(75 \%)$ and research papers writing in English (80\%). Therefore, the main objective of the language training at the elementary level is the pedagogical assistance to the professional foreign language writing formation.

Pedagogical assistance. Lingva program participants are the teaching staff members, among them: graduate students and scientific degree-seeker, candidates and doctors of different sciences. The age structure of the groups is also heterogeneous, but, nevertheless, we have to deal with adult audience. Pedagogical assistance is the most relevant form of educational and pedago- 


\section{Теория и методика профессионального образования}

gical interaction for this category of students, as they have high internal and external motivation; the ability to master the language consciously by using comparative method; willingness to provide feedback and to take responsibility for the education results, as well as the willingness to work independently, including creative and exploratory tasks. But, at the same time, they need assistance and support in goals and objectives setting, in the information selection and arrangement, in overcoming stereotypes and psychological language barriers. Stimulating and encouraging are especially important for this audience, as if there are no significant results for a long time, they quickly lose self-confidence and confidence in their own abilities.

Pedagogical assistance is one of the teacher's competences relevant to the students' educational activity support, along with self-fulfillment guidance pedagogical mentoring. G.N. Serikov emphasizes that "teacher's role is to create conditions in which the person getting education could meet his emotional, nonmaterial and educational needs. This approach doesn't mean students' education guidance but support of education" [12]. This interpretation correlates with the definitions given in pedagogical dictionary, "the creation of conditions for the individual inclinations developing" [1] and Russian dictionaries, where assistance is defined as help, support, or "active participation in someone's affairs in order to facilitate, help" [9]. Burnatova N.P. reveals the career-oriented assistance as purposeful teachers' activity, career-oriented knowledge, skills and aimed at providing qualified help for students in professional self-determination [2]. Young people self-determination pedagogical assistance is considered by Lukyanov V.M. both as psychological and pedagogical activity and as specially organized, purposeful process of professional self-determination intensification in the course of pedagogical interaction [10]. Prediger M.L. identifies the following basic principles of the pedagogical assistance to the professional selfdevelopment motivation organization: the principle of activity self-regulation, facilitation, creativity [11]. In the context of vocational education G.N. Serikov interprets pedagogical assistance as "a special kind of social influence" by presenting systematic and interpreted information about the social experience, the conditions organization for the social experience mastering, educational activity stimulation, and effectiveness supervision [12].
Based on the definitions considered above the specific features of pedagogical assistance are the following:

- creation of the special conditions for the accumulated social experience mastering;

- assistance and support in the social experience mastering;

- subject-subject relationship implementation in the form of cooperation, coordination, compromise;

- taking into account individual and personal characteristics of the educational process participants;

- the responsibility for the results of education transferring from the teacher to the learner.

Teaching staff writing. We start pedagogical assistance with the selection of information which is useful for the students. This information is adapted to the requirements of the State Educational Standard and to the people peculiarities. The guidelines for the pedagogical assistance content selection are the specific features of writing as a type of speech [13]. They are defined by the system of linguistic representation and the recipient information perception nature.

Writing is a speech shown on paper, birch bark, stone, cloth, or any other surface using written symbols - graphic signs. Using writing allows you to select the language means deliberately, to build a sentence in accordance with the topic specified, correct and improve the text, which contributes to the more complex syntactic structures using, logic, consistency, coherence of presentation, and the normative speech following [15].

Writing is an independent system of communication which has its own characteristics in both the communicative act organization and in the language means choosing:

1. Writing is deployed in a static space, so the writer has the opportunity to come back to what is written, think about it, and use the reference books.

2. The typical feature of writing is strict following the rules of literary language.

3 . Writing is focused on the "book" vocabulary: there are more common words with generalized abstract meaning, scientific terms and official business expressions.

4. The syntax in writing is more complicated: it is characterized by the composite sentences using with conjunction connection. Simple sentences are expended by common secondary and homogeneous parts of the sentence, etc. 
5. Derived prepositions and conjunctions are used more frequently in writing.

6. Writing is focused on the organs of vision perception, so it has a clear structure and formal organization (the numbering, paragraphs, and links).

The object of our study is the professional foreign language writing of the University teaching staff. Everyone who works in a particular professional field, uses language as a means of communication and as a tool for professional activities. His speech is specialized and is full of particular terms and professionalism. Linguists have different interpretations of the term: "professional speech is social and communicative system using professionally marked units of language" (Tumina L.E.) [6]; "Professional speech linguistic communication carried out in professional activity in accordance with a certain genre affiliation" (N.K. Garbowski) [4]; "Professional speech - linguistic communication, characterized by the use of professional vocabulary" (B.N. Golovko) [5]. Having analyzed the existing concept interpretation, we came to the following conclusion that professional speech is a communication carried out with the help of special professionally marked language tools. It includes the following components:

- specialized communication orientation;

- focus on the direct communication process;

- professional speech and language system correlation;

- professional statements compliance with different styles and genres of speech.

The teaching staff professional writing specific character results from the fact that the professional activity of the university lecturer has two components: the activity of the teacher and scientist. Professional lecturer speech, first of all, is the means for information transfer, a special tool for training and education. The university lecturer competences with professional foreign language writing skills usage include:

1) writing plans and notes for lectures and practical classes,

2) electronic versions of lectures preparation,

3) making presentations for lectures,

4) study guides writing,

5) methodological guidelines writing,

6) e-mail tutorials and other forms of written communication.

The main aim of communication in the scientific research field is statement of scientific concepts and conclusions. The competences of the university lecturer, carrying out research activities with professional foreign language writing skills, include:

1) research papers writing,

2) books and studies writing,

3) theses and abstracts writing,

4) reviewing and annotation,

5) paperwork for foreign grants,

6) correspondence with foreign colleagues.

Thus, a professional lecturer writing is a complex integrative concept, which includes two components - writing for teaching purposes and academic writing, featured by the use of special vocabulary and manifested in diverse situations of written communication.

Having analyzed the concept of "pedagogical assistance" and "professional writing" we have come to the conclusion that the pedagogical assistance to the professional foreign language writing formation is the process of creating special conditions for mastering foreign language social experience in writing, which includes the presentation of the information selected and organized according to the professional foreign language competences, the educational activities stimulating and effectiveness supervision.

Pedagogical assistance implementation. Pedagogical assistance can be divided into two stages: the first stage -preparatory, when special pedagogical conditions are designed and educational material is selected, and the stage of conditions creation and assistance implementation in the course of educational and pedagogical interaction. At the preparatory stage organizational and pedagogical conditions are designed i.e., selection of organizational forms adequate to the pedagogical assistance purposes; material and technical conditions are provided: the classrooms with a round table to facilitate dialogue and views exchange, computers and projectors to intensify and visualize the educational process, as well as online support for the extracurricular time communication. Information recourses and methodological support also takes place at this stage: students are provided with all the necessary manuals in electronic form or informed where they can be ordered and purchased. The list of recommended literature for a more detailed consideration of the subjects you are interested in is made up.

Pedagogical assistance at this stage is also the selection of educational material corresponding the goals of the educational process. 


\section{Теория и методика профессионального образования}

Since the purpose of the elementary stage training is lecturer writing formation, the following substantial aspects were included in the curricular:

1) Key patterns for abstracts;

2) Positions, scientific degrees, rank translation;

3) Proper names transcription and transliteration;

4) The structure of simple and composite English sentence. The types of sentences;

5) Rules of punctuation;

6) Meansof logical coordination;

7) Complex prepositions and conjunctions;

8) Headings' translation;

9) Attribute group translation;

10) The special vocabulary: AWL;

11) Pseudo international vocabulary;

12) Abstract and review structure;

13) Primary and secondary genres of writing (Articles, studies, novels, annotations, abstracts, reviews, theses, etc.);

14) Structure and composition of scientific term.

This list may be modified or expanded, depending on the needs of a specific student's audience during educational and pedagogical interaction as the adult audience is always ready to give feedback about their language needs and willing to share their experience.

The beginning of the implementation stage is the creation of psycho-pedagogical conditions, i.e. psychologically comfortable, friendly atmosphere in class, facilitating the elimination of the language barrier, subject-subject, partnership relations within the group, regardless of age, rank and position.

Despite the fact that the adult audience is quite motivated, the assistance in goals and objectives specifying is required. It takes place at introductory lesson in the form of the conversation, questioning and survey. The overall objective is specified in the of each lesson tasks, which are pragmatic because lecturers will not learn anything for the future sake, they need to understand why they have to learn this or that material and how it can be used in their professional activities.

The traditional or academic assistance is quite effective for the adult audience. It means that there is a presentation of theoretical material in the form of tables and diagrams with illustrative examples and testing of this material by completing the large amount of substitution, transformation, reproductive and productive exercises. This is due to the fact that adults are able to concentrate and to focus on one activity longer in comparison with other categories of students. Since the assistance objective is a writing formation, much attention is paid to the written exercises: essays, abstracts, summaries writing, correspondence with a lecturer via the Internet, making notes, writing dictations, finding and correcting mistakes in the texts and etc. Assistance also occurs in the form of "Publishing activity" role-play, where all the participants are divided into publishers and authors. During the game, all the stages of research paper in English publication are modeled.

One of the functions of the lecturer conducting pedagogical assistance is to help his student in choosing their own educational path and in the unsupervised work organization. As a specialist, he can tell each student, which aspects or language skills require additional training and inform about new methods, techniques, approaches, online resources, so that everyone can choose something that fits his individual abilities and needs.

Formation of different skills in the adult student groups usually takes more time due to subjective and objective reasons. Therefore, the issues of pedagogical support and encouragement are of particular importance. You can use different kinds of incentives from the progress tests, to the best students diplomas and medals awarding ceremony. It is especially important to emphasize even the smallest achievements of students at each class, as the lecturers have a tendency to perfectionism - the lack of words can be the stumbling block in communication for them, although they can paraphrase and explain in other words.

Conclusion. Thus, the pedagogical assistance to the writing formation is a special form of educational and pedagogical interaction. Educational and pedagogical interaction is the interaction between students and teachers, aimed at joint performance of their functions and students' writing skills formation. The participants of educational process are partners. Educational and pedagogical interaction can be carried out by means of direct oral and written communication, joint solving of educational problems, and mutual assistance to each other. 


\section{References}

1. Bim-Bad B.M. Pedagogicheskiy entsiklopedicheskiy slovar' [Pedagogic Encyclopedic Dictionary]. Moscow, Bol'shaya Rossiyskaya Entsiklopediya Publ, 2002, 528 p.

2. Burnatova N.P. Formirovanie gotovnosti pedagogov $k$ proforientatsionnomu sodeystviyu shkol'nikam (V sisteme povysheniya kvalifikatsii). Dis. kand. ped. nauk [Formation of Teachers' Readiness to the Career-oriented Student Assistance (in Advanced Training System). Dis. Cand. (Pedagogy)]. Chelyabinsk, 2004. 192 p.

3. Federal'nyy Zakon "Ob obrazovanii $v$ Rossiyskoy Federatsii" [Federal Law "On Education in the Russian Federation"]. Available at: http://www.Minobrnauki.rf.pdf (accessed 2.02.2016).

4. Garbovskiy N.K. Teoriya perevoda [Translation Theory]. Moscow, MGU Publ., 2004. 544 p.

5. Golovko B.N. Intertekst $v$ massmediynom diskurse [Intertext in the Mass Media Discourse]. Moscow, Stereotip Publ., 2014. 264 p.

6. Ippolitova N.A., Ladyzhenskaya T.A., Savova M.R., Smelkova Z.S., Tumina L.E. Ritorika [Rhetoric]. Moscow, Akademiya Publ., 1998. $285 \mathrm{p}$.

7. Khomutova T.N. [Language Support of Scientific and Educational Projects "Lingva" Program]. Aktual'nye voprosy sovremennogo universitetskogo obrazovaniya: materialy IX Rossiysko-Amerikanskoy nauchno-prakticheskoy konferentsii, 15-17 maya 2006 g. [Actual Problems of Modern University Education: Proceedings of the IX Russian-American Scientific Conference, May 15-17, 2006]. 2006, pp. 296-300. (in Russ.)
8. Kotlyarova I.O. [Model of the University Teaching Staff Readiness for International Cooperation]. Bulletin of the Chelyabinsk State Academy of Culture and Art, 2015, no. 2(42), pp. 161-168. (in Russ.)

9. Kuznetsov S.A. Bol'shoy tolkovyy slovar' ru sskogo yazyka [The Great Russian Language Dictionary]. St. Petersburg, Norint Publ., 2000. $1536 \mathrm{p}$.

10. Luk'yanov V.M. Pedagogicheskoe sodeystvie samoopredeleniyu molodezhi na voennuyu professiyu. Dis. kand. ped. nauk [Pedagogical Assistance to Self-determination of Young People in the Military Profession. Dis. Cand. (Pedagogy)]. Chelyabinsk, 1999. 158 p.

11. Prediger M.L. [Pedagogical Assistance to the Professional Self-development Motivation Formation of University Students]. Basic Research, 2013, no. 11-3, pp. 574-577. (in Russ.)

12. Serikov G.N. Obrazovanie i razvitie cheloveka [Education and Human Development]. Moscow, Mnemozina Publ., 2002. 416 p.

13. Volchenkova K.N. [Content of the "Academic Writing" Course for the Teaching Staff of the University]. Nauka YuUrGU: materialy 67-y nauchnoy konferentsii [SUSU Science: Materials of 67th Scientific Conference], 2015, pp. 1036-1041. (in Russ.)

14. Volchenkova K.N., Katochkov V.M., Kotlyarova I.O. [Research of Lectures' Further Linguistic Education Management in the National Research University]. Bulletin of the South Ural State University. Ser. Education. Jurisprudence, 2014, vol. 6, no. 2, pp. 18-25. (in Russ.)

15. Zherebilo T.V. Slovar' lingvisticheskikh terminov [Linguistic Terms Glossary]. Nazran, Piligrim Publ., 2010. 720 p.

Received 1 March 2016 


\title{
ПЕДАГОГИЧЕСКОЕ СОДЕЙСТВИЕ СТАНОВЛЕНИЮ ПРОФЕССИОНАЛЬНОЙ ПИСЬМЕННОЙ РЕЧИ СЛУШАТЕЛЕЙ ПРОГРАММЫ «ЛИНГВА» НА НАЧАЛЬНОМ ЭТАПЕ ЛИНГВИСТИЧЕСКОЙ ПОДГОТОВКИ
}

\author{
М.В. Цытович \\ Южно-Уральский государственный университет, г. Челябинск
}

\begin{abstract}
Дается обоснование значимости становления профессиональной иноязычной письменной речи преподавателей, вызванной необходимостью публиковать статьи в рецензируемых журналах, входящих в базы Scopus и Web of Science. Посредством анализа литературы выделены особенности педагогического содействия, которые делают его наиболее соответствующей формой учебно-педагогического взаимодействия со взрослой аудиторией. Обобщенное понятие «содействие» было конкретизировано применительно к становлению письменной речи преподавателей университета. В ходе социологического опроса и анализа профессиональной деятельности было выявлено, что профессиональная письменная речь преподавателя включает две составляющие: письменная речь преподавателя и письменная речь ученого. На основании этого сформулированы компетенции преподавателя с использованием профессиональной иноязычной письменной речи. Результаты исследования могут быть использованы для развития программ лингвистической переподготовки и повышения квалификации профессорско-преподавательского состава университета.

Ключевые слова: педагогическое содействие, учебно-педагогическое взаимодействие, письменная речь, профессиональная письменная речь преподавателя, профессорскопреподавательский состав.
\end{abstract}

\section{Литература}

1. Педагогический энииклопедический словарь / гл. ред. Б.М. Бим-Бад. - М.: Нач. изд-во «Большая Российская энииклопедия», 2002. - 528 c.

2. Бурнатова, Н.П. Формирование готовности педагогов к профориентационному содействию школьникам (В системе повышения квалификации): дис. ... канд. пед. наук / Н.П. Бурнатова. Челябинск, 2004. - 192 с.

3. Федеральный Закон «Об образовании в Российской Федерачии». - http://www. Минобрнауки. ph.pdf.

4. Гарбовский, Н.К. Теория перевода: учеб. / Н.К. Гарбовский. - М.: Изд-во Моск. ун-та, 2004. $-544 c$.

5. Головко, Б.Н. Интертекст в массмедийном дискурсе / Б.Н. Головко. - М.: Изд-во Стеpeomun, 2014. - 264 c.

6. Риторика: учеб. пособие / под ред. Н.А. Ипполитовой, Т.А. Ладыженской, М.Р. Савовой, 3.С. Смелковой, Л.Е. Туминой. - М.: Издат. иентр «Академия», 1998. - 285 с.

7. Хомутова, Т.Н. Программа лингвистической поддержки научных и образовательных проектов «Лингва» / Т.Н. Хомутова // Актуальные вопросы современного университетского образования: материаль ІХ Рос.-Америк. науч.-практ. конф., 15-17 мая 2006 г. - СПб.: Изд-во РГПУ им. А.И. Гериена, 2006. - С. 296-300.

8. Котлярова, И.О. Модель развития готовности профессорско-преподавательского состава университета к международному сотрудничеству / И.О. Котлярова // Вестник Челяб. гос. академии культуры и искусств. - 2015. - № 2 (42). - С. 161-168.

9. Большой толковый словарь русского языка / сост. и гл. ред. С.А. Кузнечов. - СПб.: Норинт, 2000. -1536 c. 
10. Лукьянов, В.М. Педагогическое содействие самоопределению молодежи на военную профессию: дис. ... канд. пед. наук / В.М. Лукьянов. - Челябинск, 1999. - 158 с.

11. Предигер, М.Л. Педагогическое содействие формированию мотивации профессионального саморазвития у студентов вуза / М.Л. Предигер // Фундамент. исследования. - 2013. № 11-3. - C. 574-577.

12. Сериков, Г.Н. Образование и развитие человека / Г.Н. Сериков. - М.: Мнемозина, 2002. $416 c$.

13. Волченкова, К.Н. О содержании курса «Academic writing» для профессорско-преподавательского состава университета / К.Н. Волченкова // Наука ЮУрГУ: материаль 67-й науч. конф., апрель 2015 г. - Челябинск: Издат. иентр ЮУрГУ, 2015. - С. 1036-1041.

14. Волченкова, К.Н. Исследование управления дополнительным лингвистическим образованием преподавателей в начиональном исследовательском университете / К.Н. Волченкова, В.М. Каточков, И.О. Котлярова // Вестник ЮУрГУ. Серия «Образование. Педагогические науки». - 2014. - T. 6, № 2. - C. 18-25.

15. Словарь лингвистических терминов / Т.В. Жеребило. - Изд. 5-е, испр. и доп. - Назрань: Изд-во «Пилигрим», 2010. - 720 с.

Цытович Мария Витальевна, кандидат педагогических наук, доцент кафедры английского языка, Южно-Уральский государственный университет, г. Челябинск, tcytovichmv@susu.ru.

Поступила в редакцию 1 марта 2016 г.

\section{ОБРАЗЕЦ ЦИТИРОВАНИЯ}

Tsytovich, M.V. Pedagogical assistance to "Lingva" program participants professional writting formation at the elementary stage of language training / M.V. Tsytovich // Вестник ЮУрГУ. Серия «Образование. Педагогические науки». - 2016. - Т. 8, № 2. - C. 41-47. DOI: $10.14529 /$ ped 160206

\section{FOR CITATION}

Tsytovich M.V. Pedagogical Assistance to "Lingva" Program Participants Professional Writting Formation at the Elementary Stage of Language Training. Bulletin of the South Ural State University. Ser. Education. Educational Sciences. 2016, vol. 8, no. 2, pp. 41-47. DOI: 10.14529/ped160206 